\title{
Identification of Phytotoxic and Phytopathogenic Fungi on Grains and Wheat Seedlings
}

\author{
A.V. Pankova \\ Department of Biochemistry and Biotechnology, Institute of \\ Fundamental Medicine and Biology \\ Kazan Federal University, KFU \\ Kazan, Russian Federation \\ apankova@dia-m.ru
}

\section{D.V. Afordoanyi}

Department of Biochemistry and Biotechnology, Institute of Fundamental Medicine and Biology

Kazan Federal University, KFU

Kazan, Russian Federation

dafordoan@gmail.com

A.R. Valiev

Center of agro ecological research

Kazan State Agrarian University, KSAU

Kazan, Russian Federation

ayratvaliev@mail.ru

\author{
L.R. Valiullin \\ Department of tissue technologies and preparation \\ production \\ Federal Center for Toxicological and Radiological Safety, \\ FCTRS \\ Kazan, Russian Federation Country \\ valiullin27@mail.ru
}

R.I. Safin

Center of agro ecological research

Kazan State Agrarian University, KSAU

Kazan, Russian Federation

radiksaf2@mail.ru

\section{R.M. Nizamov}

Center of agro ecological research

Kazan State Agrarian University, KSAU

Kazan, Russian Federation

nizamovr@mail.ru

\author{
S.Z. Validov \\ Laboratory of structural biology, \\ Institute of Fundamental Medicine and Biology \\ Kazan Federal University, KFU \\ Kazan, Russian Federation \\ szvalidov@kpfu.ru
}

\begin{abstract}
Fungal phytopathogens are responsible for significant losses in agriculture worldwide. Diagnosis of seed infestation by fungal strains causing plant diseases or producing toxins is important for sustainable agriculture. Since plants are always colonized by fungal strains there is a demand in approaches for reliable discrimination between harmless and hazardous fungi both in grains. We tested phytotoxic properties, mycotoxin production and colonization of wheat seedlings among 11 fungal isolated obtained from wheat grains of different varieties. The isolates were identified as Alternaria tenuissima, Alternaria infectoria, Bipolaris sorokiniana Alternaria arborescens, Alternaria alternata and Alternaria rosae. Strains $A$. tenuissima $A B-F$ 72, $A$. arborescens $A B-F 73$, A. alternata $A B-F 75, A$. rosae $A B-F 77$ were producing phytotoxins inhbiting growth of wheat seedling. Four strains: B. sorokiniana $\mathrm{AB}-\mathrm{F}$ 61, $A$. arborescens $\mathrm{AB}-\mathrm{F}$ 73, $A$. alternata $\mathrm{AB}-\mathrm{F} 74, A$. rosae $\mathrm{AB}-\mathrm{F} 77$ were producing mycotoxins. Five strains $A$. rosae $\mathrm{AB}-\mathrm{F} 77, A$. tenuissima $\mathrm{AB}-\mathrm{F}$ 76, $A$. infectoria AB-F 78 and $A$. infectoria AB-F 84 showed heavy colonization of
\end{abstract}

wheat plantlets suggesting that these strains can be pathogenic to wheat. The results show that toxin production is not an obligatory characteristic for phytopathogenic strain, therefore using of proliferation of fungal strain in seedling tissue can be added as an additional test to seed quality evaluation.

Keywords - fungal plant disease; mycotoxins, phytopathogen detection; qPCR; Alternaria sp.

\section{INTRODUCTION}

Plant diseases caused by fungal phytopathogens are a serious threat to food security worldwide [1]. Since approximately ten percent of agricultural products are lost due to plant infection by phytopatogenic fungi on different stages of vegetation [2], it is crucial to develop an effective tool for the detection and recording of pathogenic microflora in the early stages of plant development. 
An approach, which is routinely used for the estimation of fungal contamination, is based on the isolation of plant colonizing fungi on selective media and characterization of isolates. Uneven growth of different fungal strains is a major drawback of this approach. This problem can be partially solved using selective media, which requires additional time for analysis, as well as special knowledge of nutrient preferences and cultural characteristics of certain species of phytopathogenic microflora. However, unculturable species of fungi remain unaccounted.

Detection based on PCR methods is based on the amplification of the genus- and species-specific DNA sequences. This allows the obtaining of accurate data on the qualitative and quantitative composition of the microflora of the analyzed sample without the media cultivation stage, thereby identifying all microorganisms through their DNA or RNA of expressed genes. Methods which do not require cultivation can give more accurate evaluation of fungal strains present in plant materials. For instance, immunological detection and qPCR technics targeting genus- and species-specific DNA sequences enables direct estimation of fungi in planta. Correlation between DNA of Fusarium culmorum and wheat infection was demonstrated by [3]. Statistically, important relation was detected between the degree of wheat infection and deoxyvalenol concentration in grain [4]. Differences in fungal DNA level were demonstrated when tomato was infected with pathogenic and non-pathogenic strains of Fusarium oxysporum [5]. Moreover fungal DNA concentration was in good correlation with disease severity, revealing influence of biocontrol strain on development of Forl ZUM2407 in tomato [6].

Multi-copy and single-copy targets can be used for qPCR analysis. Ribosomal operon provides large variety of sequences presented in many copies which confer ultimate sensitivity to qPCR tests. On the other hand, a different copy number of ribosomal operon per genome in different fungal species make these sequences inconvenient for comparison of strains from different species within one sample. qPCR tests based on single copy sequence are less sensitive; nevertheless they provide possibility to estimate amounts of strains of different species simultaneously. For example genomes of fungi harbor only single copy for highly conservative $\beta$-actine gene allowing its use for quantitative estimation of fungal cells in samples of interest [7] and also phylogenetic research even on other fungi groups.

In this work, we developed a simple and reliable method for quantification of plant colonizing fungi by using primers targeting $\beta$-actine gene for $\mathrm{qPCR}$ analysis.

\section{MATERIALS AND METHODS}

\section{A. Strains and growth conditions}

Strains used in this work were isolated from grains of Triticum aestivum L. Table 1.

Strain Fusarium oxysporum f. sp. radices-lycopersici ZUM2407 (Forl ZUM2407) was used as an incompatible pathogen for wheat inoculation.

This work was financed by Ministry of Education of Russian Federation. Subsidy number is 14.610.21.0017 (Project \# RFMEFI61017X0017)
TABLE I. FUNGAL STRAINS ISOLATED IN THIS WORK

\begin{tabular}{|l|c|c|}
\hline \multicolumn{1}{|c|}{ Species } & $\begin{array}{c}\text { Source, variety } \\
\text { of } \text { Triticum } \\
\text { aestivum }\end{array}$ & $\begin{array}{c}\text { GenBank } \\
\text { Accession N. } \\
\text { of ITS region }\end{array}$ \\
\hline $\begin{array}{l}\text { Bipolaris sorokiniana AB- } \\
\text { F 61 }\end{array}$ & Ekada 70 & KX622092 \\
\hline $\begin{array}{l}\text { Alternaria tenuissima AB- } \\
\text { F 72 }\end{array}$ & Lubava & KX622103 \\
\hline $\begin{array}{l}\text { Alternaria arborescens AB- } \\
\text { F 73 }\end{array}$ & Lubava & KX622104 \\
\hline $\begin{array}{l}\text { Alternaria alternata AB-F 74 } \\
\text { Alternaria alternata AB-F 75 }\end{array}$ & Margarita & KX622105 \\
\hline $\begin{array}{l}\text { Alternaria tenuissima AB- } \\
\text { F 76 }\end{array}$ & Ester & KX622106 \\
\hline Alternaria rosae AB-F 77 & Ekada 66 & KX622108 \\
\hline Alternaria infectoria AB-F 78 & Ekada 66 & KX622109 \\
\hline Alternaria infectoria AB-F 84 & Simbercit & KX622115 \\
\hline $\begin{array}{l}\text { Alternaria tenuissima AB- } \\
\text { F 85 }\end{array}$ & Simbercit & KX622116 \\
\hline
\end{tabular}

To obtain fungal biomass, strains were grown in Czapec broth (Difco Laboratories, Detroit, MI, USA) for 7 days at $28^{\circ} \mathrm{C}$ in an incubator shaker approx. $100 \mathrm{rpm}$. Fungal hyphae were collected by filtering through miracloth. To isolate DNA, mycelium was frozen in liquid nitrogen and pulverized in mortar with pestle. DNA was extracted from pulverized fungal biomass using GeneJET Plant Genomic DNA Purification Mini kit (Thermo Fisher Scientific, USA) according to recommendations of the manufacturer. The intergenic sequences of the ribosomal operon ITS1 and ITS2 were used for identification of fungi.

\section{B. Phytotoxicity test and mycotoxin production}

Fungal strains inoculated in $\mathrm{CDB}$ were grown for seven days at $28^{\circ} \mathrm{C}$ under vigorous agitation. To exclude the influence of fungal hyphae, liquid fungal cultures CDB were filtered through $0,22 \mathrm{mkm}$ filters (Millipore inc., USA). Sterility of filtrates was tested by plating on CDA agar. Wheat seeds were placed in $10 \mathrm{ml}$ of undiluted, 10 and 100 times diluted cultural filtrate. For the controls sterile tap water and CDB were used. The shoot and root length of germinated seeds was scored in seven day. Filtrates from fungal strains which caused $30 \%$ or higher inhibition of germination or reduction of root and shoot length, were considered as phytotoxic.

The same filtrates were tested to reveal mycotoxin production. For this experiment, Paramecium caudatum (Ehrenberg, 1838) was used due to its characteristics as harmless, highly sensitive to environmental pollution, simple to reproduce and easy to maintain. $P$. caudatum was placed in the filtrates of fungal cultures for one hour and for the controls sterile tap water and CDB were used. The degree of toxicity of the culture filtrate was determined by the survival of micromycetes of $\mathrm{P}$. caudatum after one hour in accordance with the following scale: $80-100 \%$ - non - toxic product, $40-79 \%$ low-toxic product, $0-39 \%$ - toxic product.

\section{Seed sterilization}

Wheat seeds which surface was sterilized before fungal inoculation. Fifty seeds were submerged in $100 \mathrm{ml}$ of $70 \%$ 
ethanol and incubated at room temperature for $5 \mathrm{~min}$. Then the seeds were transferred to $100 \mathrm{ml}$ of $0.1 \mathrm{M} \mathrm{NaClO}$ and $1 \%$ SDS solution for $15 \mathrm{~min}$. To eliminate hypochlorite and SDS, the seeds were washed 10 times with $100 \mathrm{ml}$ sterile distilled water, leaving seeds for $3 \mathrm{~min}$ after each change of water. Sterilized seeds were placed on the surface of PNS agar [8]. For synchronization of growth parameters, the Petri dishes were kept at $+4^{\circ} \mathrm{C}$ for $48 \mathrm{~h}$.

Before inoculation, Petri dishes with sterile seeds were transferred to $28^{\circ} \mathrm{C}$ and incubated for $36 \mathrm{~h}$ in the dark for germination. Inoculated seedlings were sown in pots with sand moistened with PNS. The sown pots were kept in the growth chamber (Binder KBWF 720 , Germany) at $22^{\circ} \mathrm{C}$ with humidity of $70 \%$ in $16 \mathrm{~h}$ light day for 7 days. Uninoculated seedlings were used as negative control and seedlings inoculated with Forl ZUM2407, spores were considered as control for colonization with incompatible phytopathogen.

\section{DNA manipulations}

For DNA isolation, plantlets after seven days of growth were removed from sand and pulverized in liquid nitrogen. DNA from plants was extracted using GeneJET Plant Genomic DNA Purification Mini kit (Thermo, USA) according recommendations of manufacturer. Fungal DNA was isolated from mycelium of fungi grown on filter paper placed on sterile CDA plate. DNA concentration was measured using IMPLEN NanoPhotometer P360 (Life technologies, USA).

\section{E. PCR amplification and purification of $\beta$-actin gene}

A fragment of the $\beta$-actin gene was amplified using primer pair ACT 512-F (5' ATG TGC AAG GCC GGT TTC GC 3') and ACT 783-R (5' TAC GAG TCC TTC TGG CCC AT 3') [9]. PCR was carried out in MyCycler ${ }^{\mathrm{TM}}$ Thermal Cycler System (BioRad). Initial DNA denaturation at $95^{\circ} \mathrm{C}$ for $3 \mathrm{~min}$ was followed by 30 cycles of denaturation at $95^{\circ} \mathrm{C}$ during $30 \mathrm{~s}$, annealing at $55^{\circ} \mathrm{C}$ for $30 \mathrm{~s}$ and $30 \mathrm{~s}$ of elongation at $72^{\circ} \mathrm{C}$. Additional elongation step at $72^{\circ} \mathrm{C}$ for 5 min was introduced to complete DNA fragments. Reaction mixture comprised of $1 \times$ Taq-polymerase buffer, $2 \mathrm{MM}$ of $\mathrm{MgCl} 2,0,2 \mathrm{mM}$ of all four desoxyribonucleotides, $5 \mathrm{ng}$ of template DNA and 5 units of Taq-polymerase (Evrogen Ltd, Russia).

For visualization of PCR products were separated in $1.5 \%$ agarose gel in 1x TBE buffer purchased from Helicon Ltd. (Moscow, Russia). Amplified fragments of $\beta$-actin gene were purified from the gel using CleanUp Kit (Evrogen Ltd, Russia).

\section{$F$. Analysis of fungal proliferation using $q P C R$}

To estimate proliferation of fungi in plant tissues amount of fungal DNA was determined using qPCR mix-HS SYBR (Evrogen Ltd, Russia). $\beta$-actin gene was used as a target. Reaction mix comprised of $5 \mu \mathrm{l}$ of qPCRmix-HS SYBR, $5 \mathrm{ng}$ template DNA and 10pM of primers ACT 512-F and ACT 783$\mathrm{R}$ [9]. Final volume of $25 \mu \mathrm{l}$ was reached adding $\mu \mathrm{Q}$ water. Amplification was carried out on CFX96 ${ }^{\mathrm{TM}}$ real-time PCR (BioRad) with following program: $10 \mathrm{~min}$ of initial denaturation and polymerase activation at $95^{\circ} \mathrm{C}$ was followed by 40 cycles, including 15 seconds of denaturation at $95^{\circ} \mathrm{C}, 20$ seconds of annealing at $61^{\circ} \mathrm{C}$ and 15 seconds of elongation at $72^{\circ} \mathrm{C}$. Fluorescence of intercalated SYBR Green was measured at $80^{\circ} \mathrm{C}$ to eliminate primer dimers. Melting curve was set in temperature interval from 65 to $95^{\circ} \mathrm{C}$ stepwise with steps of $0.5^{\circ} \mathrm{C}$ and $5 \mathrm{~s}$ of measurement in each cycle.

\section{G. Analysis of fungal proliferation using $q P C R$}

To estimate proliferation of fungi in plant tissues amount of fungal DNA was determined using qPCR mix-HS SYBR (Evrogen). $\beta$-actin gene was used as a target. Reaction mix comprised of $5 \mu \mathrm{l}$ of qPCRmix-HS SYBR, $5 \mathrm{ng}$ template DNA and $10 \mathrm{pM}$ of primers ACT 512-F and ACT 783-R (9). Final volume of $25 \mu \mathrm{l}$ was reached adding $\mu \mathrm{Q}$ water. Amplification was carried out on CFX96 ${ }^{\mathrm{TM}}$ real-time PCR (BioRad) with following program: $10 \mathrm{~min}$ of initial denaturation and polymerase activation at $95^{\circ} \mathrm{C}$ was followed by 40 cycles, including 15 seconds of denaturation at $95^{\circ} \mathrm{C}, 20$ seconds of annealing at $61^{\circ} \mathrm{C}$ and 15 seconds of elongation at $72^{\circ} \mathrm{C}$. Fluorescence of intercalated SYBR Green was measured at $80^{\circ} \mathrm{C}$ to eliminate primer dimers. Melting curve was set in temperature interval from 65 to $95^{\circ} \mathrm{C}$ stepwise with steps of $0.5^{\circ} \mathrm{C}$ and $5 \mathrm{~s}$ of measurement in each cycle.

To build standard curves, $\beta$-actin gene fragment of Alternaria and Bipolaris obtained by amplification was used. Standard curves comprised of seven steps of 10 -fold dilutions from $5 \times 10^{-7} \mathrm{ng}$ to $5 \mathrm{ng}$ are described in [10].

$\mathrm{Ct}$ values obtained in samples were compared with standards and extrapolated to amount of isolated DNA, considering that $1 \mathrm{ng}$ of amplified DNA correspond to $3.2 \times 10^{9}$ copies of $\beta$-actin gene fragment.

\section{H. Statistical analysis}

Statistical analysis was performed in Statistica 10 software. To evaluate statistically the important difference between fungal DNA concentration of different plant samples, dispersion analysis (ANOVA) and Tiuqi test were used.

\section{RESULTS}

\section{A. Evaluation of grain contamination}

Plating showed that $17.0-87.0 \%$ of seeds were contaminated by fungi (Table 2). Alternaria strains were found on seeds of all tested varieties except Ecada70, which was contaminated with Bipolaris strains. Seeds of Ester varieties were heavily contaminated: $87 \%$ of grains were overgrown with mycelium when placed on CDA. Seeds-Ecada, Ecada 66, Lubava and Margarita showed $37-25 \%$ fungal contamination. Seeds of Simbercit variety demonstrated lowest percentage of fungal contamination (Table 2).

\section{B. Isolation of fungal strains from wheat seeds and identification}

Single colonies of fungal strains obtained from the seeds were studied under light microscope and plated repeatedly on CDA. Ten strains were purified and maintained as cultures (Table 2). Fungal strain identification was carried out using intergenic sequences ITS1 and ITS2. BLAST searches of the obtained sequences revealed that isolated strains belong to following species: Bipolaris sorokiniana, Alternaria. alternata, $A$. arborescens, $A$. infectoria, $A$. rosae and $A$. tenuissima. The 
sequences of ITS1 and ITS2 regions of the newly isolated strains were deposited on GenBank (Table 1).

\section{Phytotoxicity assay}

Filtrates of all isolated fungal cultures were inhibiting seed germination and further development of the plantlets. Strains $A$. tenuissima $\mathrm{AB}-\mathrm{F} 72, A$. arborescens $\mathrm{AB}-\mathrm{F} 73$, A. alternata ABF 75, A. rosae AB-F 77 seem to produce phytotoxin since dilutions of 10 and 100 fold of their culture filtrate inhibited seed germination. Filtrates of the rest of the fungal strains had no inhibitory influence when they were applied on seeds after dilution of 10 and 100 fold (Table 3).

\section{Mycotoxin detection}

Strains $A$. tenuissima $\mathrm{AB}-\mathrm{F} 76, A$. rosae $\mathrm{AB}-\mathrm{F} 77, A$. infectoria $\mathrm{AB}-\mathrm{F} 84$, A. tenuissima $\mathrm{AB}-\mathrm{F} 85$ were considered as non-toxic since survival of $P$. caudatum in cultural liquid was 80.0-85.0\%. Lethal concentrations (LC) of A. tenuissima AB-F 72, A. alternata AB-F 75 were moderately toxic demonstrating survival of $60.0-75.0 \%$. Four strains $B$. sorokiniana AB-F 61, A. arborescens AB-F 73, A. alternata AB-F 74, A. rosae AB-F 77 were producing toxic metabolites: in their LCs, survival of paramecia was not higher than $30.0 \%$ (Table 3 ).

\section{E. Phytopathogenisity test}

Presence of fungi was demonstrated in all samples analyzed. Amount of fungi found in controls was 0.56-0.67 copy/ng which was considered as basal level.

B-actin copy number calculated per ng of isolated DNA varied between samples in a range from 2.91 to 14.99 . The minimal number of $\beta$-actin copies was demonstrated for strains $A$. arborescens AB-F 73 (2.91 \pm 0.69 copies/ng), B. sorokiniana AB-F 61 (4.75 \pm 1.77 copies/ng), A. alternata AB-F $75(5.98 \pm$ 1.81 copies/ng), A. alternata AB-F 74 (5.39 \pm 1.12 copies/ng), A. tenuissima AB-F 72 (9.34 \pm 3.33 copies/ng).

TABLE II. WHEAT GRAIN INFESTATION

\begin{tabular}{|c|l|c|}
\hline Triticum aestivum variety & Species & $\begin{array}{c}\text { Infested seeds, } \\
\mathbf{\%}\end{array}$ \\
\hline \multirow{2}{*}{ Ekada 70} & B. sorokiniana & 31.0 \\
\hline \multirow{2}{*}{ Margarita } & A. tenuissima & 30.0 \\
\cline { 2 - 3 } & A. arborescens & 31.0 \\
\hline \multirow{2}{*}{ Ester } & A. alternata & 50.0 \\
\cline { 2 - 3 } & A. alternata & 37.0 \\
\hline \multirow{2}{*}{ Ekada 66} & A. tenuissima & 87.0 \\
\hline \multirow{2}{*}{ Simbercit } & A. rosae & 25.0 \\
\cline { 2 - 3 } & A. infectoria & 25.0 \\
\hline & A. infectoria & 9.0 \\
\cline { 2 - 3 } & A. tenuissima & 8.0 \\
\hline
\end{tabular}

TABLE III. TOXICITY OF CULTURAL LIQUID (CL) TESTED ON WHEAT SEEDLINGS AND PARAMECIA

\begin{tabular}{|l|c|c|c|c|}
\hline \multirow{2}{*}{ Fungal strains } & \multicolumn{2}{|c|}{ Phytotoxicity, \% } & $\begin{array}{c}\text { Survival of } \\
\text { P.caudatum, } \\
\text { \% }\end{array}$ \\
\cline { 2 - 4 } & $\mathrm{CL}$ & $\begin{array}{c}\mathrm{CL} \\
(1: 10)\end{array}$ & $\begin{array}{c}\mathrm{CL} \\
(1: 100)\end{array}$ & 30.0 \\
\hline B. sorokiniana AB-F 61 & 87.0 & 52.8 & 29.3 & 75.0 \\
\hline A. tenuissima AB-F 72 & 92.5 & 71.9 & 44.7 & 30.0 \\
\hline A. arborescens AB-F 73 & 96.1 & 59.9 & 53.0 & 30.0 \\
\hline A. alternata AB-F 74 & 79.4 & 48.0 & 48.9 & 60.0 \\
\hline A. alternata AB-F 75 & 87.7 & 50.1 & 35.0 & 80.0 \\
\hline A. tenuissima AB-F 76 & 90.9 & 47.3 & 27.6 & 30.0 \\
\hline A. rosae AB-F 77 & 84.6 & 50.1 & 59.9 & 80.0 \\
\hline A. infectoria AB-F 78 & 92.1 & 42.2 & 22.7 & 80.0 \\
\hline A. infectoria AB-F 84 & 90.0 & 64.3 & 25.2 & 85.0 \\
\hline A. tenuissima AB-F 85 & 94.3 & 56.9 & 27.4 & \\
\hline
\end{tabular}

Five strains showed heavy colonization of wheat plantlets: strains $A$. rosae $\mathrm{AB}-\mathrm{F} 77, A$. tenuissima $\mathrm{AB}-\mathrm{F} 76, A$. infectoria AB-F 78 and AB-F 84 presenting values from $14.99 \pm 4.2785$ to $12.41 \pm 3.78$ copies $/ \mathrm{ng}$. One way analysis $(\mathrm{p}=0.403 \times 10-12)$ revealed a significant difference in the $\beta$-actin copy number which is an indication that differences in i.e. amount of fungal biomass between wheat colonizing/infecting strains are statistically true.

In particular, in the course of multiple comparisons using the Tukey test, statistically significant differences $(p<<0.05)$ in the number of copies of the actin gene in comparison with control samples were observed in plant variants treated with fungi $A$. tenuissima $\mathrm{AB}-\mathrm{F} 72, A$. tenuissima $\mathrm{AB}-\mathrm{F} 76, A$. rosae AB-F 77, A. infectoria AB-F 78, A. infectoria AB-F 84, $A$. tenuissima $\mathrm{AB}-\mathrm{F} 85$ (Fig. 1). In samples treated with micromycetes $B$. sorokiniana $\mathrm{AB}-\mathrm{F} 61, A$. arborescens $\mathrm{AB}-\mathrm{F}$ 73, A. alternata $\mathrm{AB}-\mathrm{F} 74, A$. alternata AB-F 75, the difference with the control variants was not revealed (Fig.1).

TABLE IV. PROPAGATION OF FUNGAL STRAINS IN WHEAT PLANT TISSUE TESTED BY QPCR

\begin{tabular}{|l|c|}
\hline \multicolumn{1}{|c|}{ Samples } & $\begin{array}{c}\text { Number of } \boldsymbol{\beta} \text {-actin genes copies } \\
\text { per ng of extracted total DNA }\end{array}$ \\
\hline Control Forl ZUM2407 (K1) & $0.67 \pm 0.53$ \\
\hline Control 2 PNS (K2) & $0.56 \pm 0.20$ \\
\hline B. sorokiniana AB-F 61 & $4.75 \pm 1.77$ \\
\hline A. tenuissima AB-F 72 & $9.34 \pm 3.33$ \\
\hline A. arborescens AB-F 73 & $2.91 \pm 0.69$ \\
\hline A. alternata AB-F 74 & $5.39 \pm 1.12$ \\
\hline A. alternata AB-F 75 & $5.98 \pm 1.81$ \\
\hline A. tenuissima AB-F 76 & $14.29 \pm 3.61$ \\
\hline A. rosae AB-F 77 & $14.99 \pm 4.27$ \\
\hline A. infectoria AB-F 78 & $12.46 \pm 4.71$ \\
\hline A. infectoria AB-F 84 & $12.41 \pm 3.78$ \\
\hline A. tenuissima AB-F 85 & $13.05 \pm 2.65$ \\
\hline
\end{tabular}




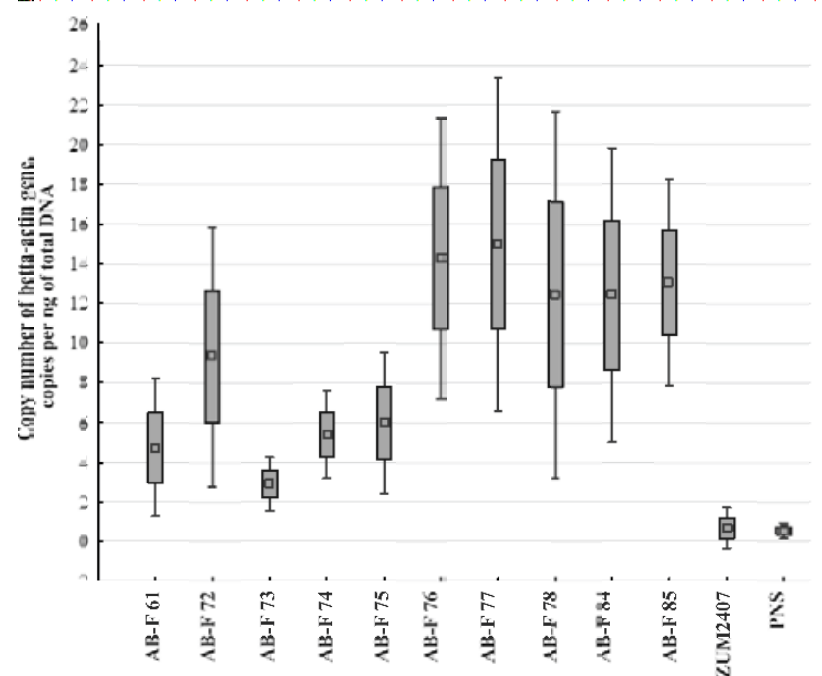

Fig 1 - Multiplication of fungal strains in wheat plant tissue. Open square shows mean value. Rectangles filled gray represent standard deviation values. Bars represent Mean value multiplied by 1.96 , multiplied by corresponding standard deviation

\section{DISCUSSION}

Fungal infestation has direct influence on shelf-life of seeds and crop productivity. It is also an important quality marker for crops which are to be used for food and feeding. Presence and multiplication of fungi can result in rotting and accumulation of mycotoxins.

Nowadays biological methods routinely used for estimation of seed quality are based on isolation and identification of fungal strains. These methods do not estimate pathogenic potential of strains or mycotoxin production. Putative disease is predicted on the basis of fungal species found on seeds. (Fusarium, Alternaria, etc.).

Infestation of wheat samples, analyzed in this work, varied from $17 \%$ to $87 \%$. According to international standards GOST $12038-84$, degree of seed infestation with molds is evaluated on the base of following scale: if the number of seeds covered with fungi mold is up to $5 \%$, the damage is considered weak, up to $25 \%$ - moderate and more than $25 \%$ then the seed is recognized as heavily infested. Among samples analyzed, only seeds of Simbercite variety can be considered moderate with the rest of the seeds heavily infestated with fungi

With the help of microbiology methods in the assessment of seeds infected by fungi, we have been able to isolate fungi Bipolaris sorokiniana. For all analyzed varieties (except Simbircite), isolates were identified as a member of the genus Alternaria. The most dangerous species for plants are the pathogenic species transmitted through seed, Tilletia caries and Ustilago hordei (solid smut), Ustilago tritici and Ustilago nuda (the head smut) and Fusarium (Fusarium head blight, root rot), in addition, these fungi produce the most dangerous toxins. These species were not seen in the studied samples of grains, which indicates their safety.

Cultural liquid from four strains Bipolaris sorokiniana and $A$. alternata isolated in this work showed a significant reduction of the viability of paramecia, indicating the synthesis of toxic metabolites by these strains. Representatives of the genus Alternaria are able to synthesize dangerous metabolites, including dibenzo-a-pyrones (alternariol, monomethyl ester of alternariol, altenuene, tentoxin), tetra-mina (tenuazonic acid) and derivatives of perylene (altertoxinses I, II and III) [11].

It is necessary to discriminate phytotoxicity and pathogenicity. The later is a qualitative characteristic of a species determined by its genotype; it is a potential ability of the pathogen to be a causative agent to an infectious process. Pathogenicity factors are related to structural elements of microbial cell and its metabolism. They allow the pathogenic microorganism not only to penetrate and survive, but also to multiply, spread in the tissues and organs of the animal (plant) and actively influence its functions.

In this work, to determine the degree of pathogenicity of the studied strains of fungi, a molecular method of quantitative determination of fungi in wheat plants was used.

To date, there are several works accounting for pathogenic fungi colonizing plants $[12,13]$, ectomycorrhizal fungi in artificial media and plant seedlings $[14,15]$ and also endomycorrhizal fungi on plant roots $[16,17,18]$. However, it should be noted that not all cases with correlation between the results and the data obtained during the qPCR are controversial $[14,16]$. The proposed method for quantitative assessment of the degree of plant infection with phytopathogenic fungi is based on qPCR when using primers binding to the gene of $\beta$ actin protein.

The $\beta$-actin protein itself plays an important role in many cellular processes of eukaryotic organisms - cytoskeleton formation, cell growth, division and differentiation, cellular mobility and much more [19, 20, 21, 22]. Despite the diversity of functions of this protein, the primary structure $(42 \mathrm{kDa})$ is a highly conservative form among various systematic categories of eukaryotic organisms, which makes it particularly essential for phylogenetic analysis of individual taxa [7].

Another feature of this protein is that in one haploid genome of a fungus has one copy of the highly conservative actin gene $[23,24,25,8]$ making it a convenient target for the development of a qualitative technique to produce an accurate count of fungal cells in the samples under study.

Primers for the $\beta$-actin protein encoding gene, ACT 512-F and ACT 783-R, developed by Carbone and Kohn [9], have already been successfully applied to the development of a valuable methodology for assessing the degree of fungal contamination of objects in cultural heritage or historical sites [26].

The results from qPCR analysis showed the presence of fungi in all studied plant variants. At the same time, fungi were also found in the control samples, but in trace amounts (table 4). In the case of Forl ZUM2407 (K1), there is a slight increase in the biomass of the fungus. Since the microbe is a nonpathogenic form for wheat, it does not affect the growth and development of the plant. Similar data on the spread of the pathogenic Fusarium species on a non-specific host plant were obtained in the work of [5]. 
In the case of the second control variant, when seeds of the plant were treated only with sterile PNS, there was the presence of small amounts of fungal forms due to non-sterile conditions during cultivation, in which there was a possibility of contamination with fungi from the environment.

The number of copies of the actin gene detected in the control samples was taken as a threshold with the excess in test samples testifying to the development of the pathogenic form of fungi.

The data obtained allowed us to classify six of the ten analyzed strains under analysis as phytopathogens. These species are $A$. tenuissima A B-F 72, $A$. tenuissima A B-F 76, $A$. rose AB-F 77, $A$. infectoria AB-F 78, $A$. infectoria AB-F 84, $A$. tenuissima A B-F 85.

Only 2 strains had a strong cytotoxic effect, which was characterized by the preservation of this property during multiple dilution of the culture fluid of pathogens A. tenuissima AB-F 72, A. rosae AB-F 77. This suggests that not always phytotoxic strains of microorganisms are pathogenic forms and to classify a microorganism as pathogenic species, it is not always adequate to conduct a test only to identify toxic effects.

Also the sensitivity of the qPCR method has been proven by culturing of infectious plant samples on Capek medium. In this case, the colonies of the studied fungi were not revealed. This can be explained by the type of development of pathogenic forms of fungi during their vital activity as they penetrate into the tissues and organs of the plant to colonize them. On the surface of the plant remains, trace amounts of the pathogen is quite difficult, and in most cases impossible to track, using plating methods.

In general, the obtained experimental data indicate that the proposed qPCR method for quantitative accounting of fungiplant colonizers, based on the $\beta$-actin gene, is effective and can be a fast and reliable tool for the detection of phytopathogenic microflora on plants. This approach has an apparent advantage over the traditional method of observing the infectious background, making it a distinct method in the possibility of detecting even trace amounts of fungi.

\section{Acknowledgment}

This work was financed by the Ministry of Education of the Russian Federation. A subsidy number is 14.610.21.0017 with a unique identifier of the project RFMEFI61017X0017.

\section{References}

[1] J. Flood, "The importance of plant health to food security," Food Security, vol. 2, pp. 215-231, 2010.

[2] L. Lo Presti, D. Lanver, G. Schweizer, S. Tanaka, L. Liang, M. Tollot, A. Zuccaro, S. Reissmann and R. Kahmann, "Fungal effectors and plant susceptibility," Annu Rev Plant Biol, vol. 66, pp. 513-45, 2015.

[3] C. Strausbaugh, K. Overturf and A. Koehn, "Pathogenicity and real-time PCR detection of Fusarium spp. in wheat and barley roots," Canadian Journal of Plant Pathology, vol. 27, pp. 430-438, 2005.

[4] R.Burlakoti, R. Estrada, V. Rivera, A.Boddeda, G. Secor and T.Adhikari "Real-time PCR Quantification and Mycotoxin Production of Fusarium graminearum in wheat inoculated with isolates collected from potato, sugar beet, and wheat," Phytopathology, vol. 97, pp. 835-841, July 2007.

[5] S. Validov, F. Kamilova and B. Lugtenberg "Monitoring of pathogenic and non-pathogenic Fusarium oxysporum strains during tomato plan infection," Microbial Biotechnology, vol. 4, 82-88, 2011.

[6] S. Validov, F. Kamilova and B. Lugtenberg. "Pseudomonas putida strain PCL1760 controls tomato foot and root rot in stonewool under industrial conditions in a certified greenhouse," Biological Control, vol. 48, pp. 6 $11,2009$.

[7] K. Voigt and J. Wostemeyer, "Reliable amplification of actin genes facilitates deep-level phylogeny," Microbiol. Res., vol. 155, pp. 179-195, 2000.

[8] E. Hoffland, G. Findenegg and J. Nelemans, "Solubilization of rock phosphate by rape," Plant Soil, vol. 113, pp. 161-165, 1989.

[9] I. Carbone and L. Kohn, "A method for designing primer sets for speciation studies in filamentous ascomycetes," Mycologia vol. 91, pp. 553-556, 1999.

[10] L. Schena, F. Nigro, A. Ippolito and D. Gallitelli, "Real-time quantitative PCR: a new technology to detect and study phytopathogenic and antagonistic fungi,” Eur. J. Plant Pathol., vol. 110, pp. 893-908, 2004

[11] R. Coulombe, "Alternaria toxins in Mycotoxins and phytoalexins", R. P. Sharma, D. K. Salunkhe Eds., Boca Ration: CPC Press, 1991. pp. 425 433.

[12] W. Bodles, C. Fossdal and S. Woodward, "Multiplex real-time PCR detection of pathogen colonization in the bark and wood of Picea sitchensis clones differing in resistance to Heterobasidion annosum," Tree Physiol., vol. 26, pp. 775-782, 2006.

[13] J. Böhm, R. Hahn, G. Schubert, N. Bahnweg, J. Adler, J. Nechwatal, R. Oehlmann and W. Oiwald, "Real-time quantitative PCR: DNA determination in isolated spores of the mycorrhizal fungus Glomus mosseae and monitoring of Phytophthorainfestans and Phytophthoracitricola in their respective host plants," J. Phytopathol., vol. 147, pp. 409-416, 1999

[14] R.Landeweert, C. Veenman, T. Kuyper, H. Fritze, K. Wernars and E. Smit, "Quantification of ectomycorrhizal mycelium in soil by real-time PCR compared to conventional quantification techniques," FEMS Microbiol. Ecol., vol. 45, pp. 283-292, 2003.

[15] R. Schubert, S. Raidl, R. Funk, G. Bahnweg, G. Muller-Starck and R. Agerer, "Quantitative detection of agar-cultivated and rhizotron-grown Piloderma croceum Erikss\&Hjorts by ITS1-based fluorescent PCR," Mycorrhiza, vol. 13, pp. 159-165, 2003.

[16] H. Gamper, J. Young, D. Jones and A. Hodge, "Real-time PCR and microscopy: are the two methods measuring the same unit of arbuscular mycorrhizal fungal abundance?" Fungal Genet. Biol., vol. 45, pp. 581$596,2008$.

[17] C. Tellenbach, R. Grünig and N. Sieber, "Suitability of Quantitative RealTime PCR To Estimate the Biomass of Fungal Root Endophytes,”. Appl. Environ. Microbiol., vol. 76, pp. 5764-5772, 2010

[18] A. Badri, F. Stefani, G. Lachance, L. Roy-Arcand, D. Beaudet, A. Vialle and M.Hijri, "Molecular diagnostic toolkit for Rhizophagus irregularis isolate DAOM-197198 using quantitative PCR assay targeting the mitochondrial genome," Mycorrhiza, vol. 26, pp. 721-733, October 2016.

[19] J. Wery, M. Dalderup, J. ter Linde, T. Boekhout and A. van Ooyen, "Structural and phylogenetic analysis of the actin gene from the yeast Phaffia rhodozyma," Yeast, vol. 12, pp. 641-651, 1996.

[20] P. Sheterline, J. Clayton, J. Sparrow, Actin. Protein Profile, 3ed ed., vol. 2, 1996, Academic Press Limited, London.

[21] B. Neveu, M. Michaud, F. Belzile and R. Belanger, "The Pseudozyma flocculosa actin promoter allows the strong expression of a recombinant protein in the Pseudozyma species," Appl.Microbiol. Biotechnol., vol. 74 pp. 1300-1307, 2007.

[22] A. Berepiki, A. Lichius and N. Read, "Actin organization and dynamics in filamentous fungi," Nat Rev Microbiol., vol. 2, pp. 876-887, 2011.

[23] D. Gallwitz and R. Seidel, "Molecular cloning of the actin gene from yeast Saccharomyces cerevisiae. NucleicAcidRes., vol. 8, 1043-1059, 1980.

[24] P. Mertins and D. Gallwitz, "A single intronless actin gene in the fission yeast Schizosaccharomyces pombe: nucleotide sequence and transcripts 
for medin homologous and heterologousyeast," Nucleic Acids Res., vol. 15, pp. 7369-7379, 1987.

[25] S. Fidel, J. Doonan and N. Morris, “Aspergillus nidulans contains a single actin gene which has unique intronlocations and encode say-actin," Gene, vol. 70, pp. 283-293, 1988.
[26] J. Ettenauer, G. Piñar, H. Tafer and K. Sterflinger, "Quantification of fungal abundance on cultural heritage using real time PCR targeting the $\beta$-actin gene," Front. Microbiol., vol. 28, 2014, http://doi.org/10.3389/fmicb.2014.00262. 